\title{
Orbital Complications of Functional Endoscopic Sinus Surgery
}

\author{
Valentin Stoyanov, Atanas Vlaykov, \\ Dimitar Mihailov, Pavel Dimov \\ Department of Otorhinolaryngology, \\ Trakia University, St. Zagora, Bulgaria
}

\begin{abstract}
:
Objective: Functional endoscopic sinus surgery (FESS) is an operating procedure for surgical treatment of diseases of the paranasal sinuses. There are precised indications for this surgical intervention. Like any invasive intervention there is a risk of occurrence of complications. Some of the most common are the orbital complications.

Methods: By analyzing the available literature, the authors compare and summarize the results of various studies on this subject.

Results: Orbital complications are rare but can be with severe consequences, including the complete loss of vision, and even death. Most of them after adequate treatment have not substantial implications but the underestimation can have serious consequences.

Conclusion: The first step to avoid complications is prevention. If we have doubts of complications they must be precised instantly and act responsibly towards them. In the presence of this complication, one should be immediately consulted with an ophthalmologist and periodic assessment of IOP and visual acuity.
\end{abstract}

Keywords: orbital complications, endoscopic surgery, visual disturbances

\section{Objective}

Functional endoscopic sinus surgery (FESS) is a contemporary operating procedure that has revolutionized the surgical treatment of chronic diseases of the sinuses. The founders of the endoscopic study of anatomy, pathophysiology and surgery of the nose and paranasal sinuses are two Austrian scientists Messerklinger and Stammberger [1] and David Kennedy of the United States [2]. They develop and promote modern endoscopic equipment.

During the past 20 years, endoscopic surgery has been widely used as a safe and effective treatment of diseases of paranasal sinuses. FESS concept consists of the removal of pathologically transformed tissues in the area of the osteomeatal complex (OMC), and to facilitate drainage of the cavity, while preserving the surrounding healthy mucosa. With hard fiberoptic endoscope provides excellent intraoperative visualization of the OMC which allows intervention to focus on key areas. The image can be projected onto a television monitor with a small camera attached to the eyepiece of the endoscope and using mikrodebrider removed pathologically altered tissue while preserving normal. The ultimate goal is a reasonable extension of natural openings of the sinuses [3].

Relative indications for surgery include the presence of symptomatic nasal polyps and recurrent rhinosinusitis unresponsive to adequate conservative treatment. Absolute indications are development of complications of rhinosinusitis, mucocele, allergic or invasive fungal rinosinuitis and neoplasia $[4,5]$. 


\section{Methods}

By analyzing the available literature we compared and summarized the results of various studies on this subject.

\section{Results}

Orbital complications are rare, accounting for approximately $0,12 \%$ [6] to $0.5 \%$ [7] of the ESS procedures, but can be with severe consequences, including the complete loss of vision, and even death. [8]

Risk of orbital complications during FESS exists due to the following important clinical and anatomical [9] connections:

1. The orbit is a lateral wall of the etmoidal cells.

2. Lamina papiracea (LP) is a thin bone and their integrity can be easily destroyed.

3. N. opticus (NO) is exposed to a risk, as it is located in the median plane, and closer to the side wall of the rear ethmoidal cells and the sphenoid sinus.

4. On the upper levels in the nasal cavity is localized ethmoidal artery, which is also at risk of injury.

5. Nasolacrimal duct is prone to damage, as it is located just in front of uncinat process.

The risk of injury is associated with anatomical variations, data for a previous operation, degree and severity of the disease and on the skills of the surgeon. [11]

On the other hand, the use of mechanical systems do not provide good tactile feedback to the surgeon, which is also a prerequisite for the occurrence of complications [12]

Intraorbital complications are [13]:

1. Fat tissue herniation

2. Periorbital emphysema

3. Intraorbital hemorrhage

4. Damage to eye muscles

5. Optic nerve injury

6. Inflammatory complications

7. Injury of nasolacrimal duct / sac

\section{Fat tissue herniation}

After destroying integrity of 1 . papyracea periorbital fat can pass into the nasal cavity. The state does not require active intervention if not accompanied by other symptoms.

\section{Epiphora}

It is more likely to happen if antrostomy is performed too forward with destruction of the nasolacrimal duct. Frontal sinus surgery carries a risk of damage to the nasolacrimal sac while eliminating proc. uncinatus or average antrotomy may cause a lesion in the lacrimal duct. [10] Method of choice in this condition are mono or bikanalikular stenting, dakriotsistorinostomy restoring the integrity of the nasolacrimal system [14].

\section{Intraorbital hematoma}

It can be of arterial or venous origin. Arterial bleeding from the anterior ethmoidal artery is typically or less often from the posterior a. ethmoidalis. If the vessel is damaged near to the orbital wall, there is a real risk of retraction into the orbit [15], forming large periorbital hematomas with dangerously increased intraorbital pressure.

Venous bleeding has a more favorable outcome and frequent use of mannitol and corticosteroids accompanied by orbital massage is sufficient to control the condition. Surgical treatment of hematomas include lateral canthotomy, cantholysis, endoscopic orbital decompression or external frontoethmoidal approach $[13,16]$.

When IOP is $<30 \mathrm{mmHg}$ we considered that there is no immediate risk to eyesight and blood flow to the optic nerve is good, the patient should be observed at high rates is held eye massage, systemic dexamethasone and topical beta-blockers. Hyperosmotic agents and paracentesis of the anterior chamber is generally considered to be weak or ineffective. If values continue to increase then one of the above-mentioned surgery is recommended [17].

\section{Diplopia}

Most often due to damage to the orbital muscles, and often affect the medial rectus muscle and superior oblique muscle [18].

Direct rupture, neurovascular interruption or development of adhesions to surrounding tissues can cause impairment of their function. The mechanism of injury to the eye muscles can be direct or indirect. Direct injury of the muscles occurs during surgery through surgery instruments and consists of tearing of the muscles and / or the occurrence of muscular hematoma. The indirect mechanism of the optic nerve damage occurs in the formation 
of orbital hemorrhage with possibility of increasing the intraorbital pressure and / or entrapment of intact muscle fibers in the fracture of the orbital wall. The condition is associated with diplopia, in some or all directions to eyes movements [11].

\section{Damage of n. opticus}

During FESS can be obtained as a result of gently injury, contusion or orbital hematoma which performs compression of the optic nerve or severe injury causing posterior ischemic optic neuropathy, which delayed in time leads to blindness [19]. Suspected involvement of the optic nerve should occur in the case when during surgery appeared anisocoria (due to ischaemia or damage to the nerves innervating the pupil) or if after surgery there is severe loss of vision of low pupil mouvements. In cases where this complication is consequence of compressed nerve hematoma, decompression should be performed as soon as possible because duration of optic nerve ischemia is between 90 and $120 \min [20]$.

\section{Inflammatory complications}

According to the clinical course of inflammatory orbital complications we can range them from mild (swelling of the eyelids) to very severe (cellulitis of the orbit). Depending on the nature of the inflammatory process, they are nonpurulent and purulent. Nonpurulent orbital complications included eyelid edema, cellulite and periostitis of the orbit, and the purulent are - the eyelid abscess, subperiosteal abscess and phlegmona. Optic neuritis can be both purulent and nonpurulent complication.

The presence of periorbital complications is manifests often with advanced exophtalm, progressive decrease of visual acuity, paresis of the orbital muscles that is characterized by lateral and downward deflection of the eyeball, anisocoria etc. [21,22].

\section{Subcutaneous emphysema}

Can appear if there is a small fracture of lamina papyracea, if the patient is exposed to large amounts of positive pressure after extubation, coughing, vomiting, or blowing the nose. These circumstances carry a risk of air penetration into the subcutaneous and / or orbital tissues. Treatment is usually not necessary, emphysema is absorbed within 7 to 10 days. The eyes should be examined for other complications $[6,13]$.

\section{Conclusion}

The first step to avoid complications is prevention. Technically difficult cases should not be operated by an inexperienced surgeon as he or she mastered the procedure through dissection of cadavers courses or surgical training $[23,24]$. Prevention includes preoperative evaluation of the patient's history, physical data and detailed radiological evaluation [25]. Informed consent for the procedure, which discusses potential complications, is essential.

All intraoperative orbital complications must be recognized instantly and one should act responsibly towards them. In the presence of this complication, one should be immediately consulted with an ophthalmologist and periodic assessment of IOP and visual acuity.

\section{References:}

1. Stammberger $\mathrm{H}$. The evolution of functional endoscopic sinus surgery. Ear, Nose \& Throat Journal. Jul 1994; Vol. 73, 7: 451-3.

2. Kennedy D. Functional endoscopic sinus surgery: technique. Arch Otolaryngol Head Neck Surg. 1985; 111: 643-649.

3. Setliff R, D. Parsons. The „Hummer“; new instrumentation for functional endoscopic sinus surgery. Am J Rhinol 1994; 8: 275 278.

4. Rice, H. Dale. Indications for endoscopic sinus surgery. Ear, Nose \& Throat Journal. Jul1994; Vol. 73, 7: 461-9.

5. Ehteshami S, S. Hashemi, S. Madani. Functional endoscopic sinus surgery: indications and complications. HealthMed 2012; Vol 6,11: 3665-3670

6. May M, L. Levine, S. Mester et al. Complications of endoscopic sinus surgery: analysis of 2108 patients - incidence and prevention. Laryngoscope 1994; 104:1080-1083.

7. Cumberworth V, R. Sudderick, I. Mackay. Major complications of functional endoscopic sinus surgery. Clin Otolaryngol 1994; 19: 248-252.

8. Al-Reefy M, A . Al-Amer. Optic nerve injury following functional endoscopic sinus surgery. Bahrain Medical Bulletin 2012; 34: 3.
9. Вичева Д, Е. Хойзинг. Хирургична анатомия и основни дисекционни техники на носа. Бойкинг, Пловдив 2003; 5-30.

10. Al-Mujaini A, Up. Wali, M. Alkhabori. Functional endoscopic sinus surgery: indications and complications in the ophthalmic field, Oman Med J. 2009; 24(2): 70-80.

11. Ilieva K, P. Evenes, M. Tassignon, P. Salu. Ophtalmic complications after functional endoscopic sinus surgery (FESS). Bull. Soc. Belge Ophtalmol. 2008; 308: 9-13.

12. Rene C, G. Rose, R. Lenthall, I. Moseley. Major orbital complications of endoscopic sinus surgery, Br J Ophthalmol 2001; 85: 598-603.

13. Valerie J, M. Lund, Ant. Wright et al. Complications and medicolegal aspects of endoscopic sinus surgery. J Soc Med 1997; 90: $422-428$.

14. Thomas Ho, L. Vickie. National survey on the management of lacrimal canalicular injury in the United Kingdom Clinical and Experimental Ophthalmology 2006; 34: 39-43.

15. Stankiewicz J, J. Chow. Two faces of orbital hematoma in intranasal (endoscopic) sinus surgery. Otolaryngol Head Neck Surg. 1999; 120(6): 841-7. 
16. Arvind A, D. Machin, H. Al-Jassim. Late periorbital haemorrhage following functional endoscopic sinus surgery: a caution for potential day case surgery, BMC Ear, Nose and Throat Disorders 2006; $6: 11$.

17. Graham S, K. Carter. Combined-approach orbital decompression for thyroid-related orbitopathy. Clin Otolaryngol Allied Sci. 1999; 24(2): 109-13.

18. Graham S, J. Nerad. Orbital complications in endoscopic sinus surgery using powered instrumentation. Laryngoscope 2003; 113(5): 874-878.

19. Wu W, D. Sia, P.Cannon et al. Visual acuity recovery in traumatic optic neuropathy following endoscopic optic nerve decompression: a case report. Ophthal Plast Reconstr Surg 2011; 27(1): e13-15.

20. Bhatti M, J. Stankiewicz. Ophthalmic complications of endoscopic sinus surgery. Surv Ophthalmol 2003; 48(4): 389-402.

21. Стоянов В, Д. Михайлов, Ат. Влайков, Зл. Трифонов, Ив. Нейчев. Орбитални усложнения от риногенен произход-с принос от един случай. Реферативен бюлетин по Офталмология 2010 2: 44-48.

22. Ценер X. Заболявания на ушите, носа и гърлото. „Шаров“ 1998, 240.

23. Stankiewicz J. Complications of endoscopic intranasal ethmoidectomy. Laryngoscope 1987; 97: 1270-1273.

24. Вичева Д, E, Huizing. Роля на преоперативното планиране при пациенти с различен тип назална деформация. VII Национален конгрес по оториноларингология, Пловдив, 18-20.10.2001, Сборник; 302-310.

25. Вичева Д, Х. Василев, Р. Бенчев, О. Деспотов. Предоперативна и следоперативна акустично-ринометрична оценка при риносептопластика. VII Национален конгрес по оториноларингология, Пловдив, 18-20.10.2001, Сборник; 222-226.
26. ВИЧЕВА, Д., Акустична ринометрия. Монография, 2003 год., Издателство „Бойкинг“ - Пловдив. ISBN 954-91 362-1-3, 2003г.

27. ВИЧЕВА, Д. Технически аспекти и възможности на метода акустична ринометрия. Оториноларингология, ISSN 0473 5609; Година IV; 3-4, 2000, стр. 59-66.

28. ВИЧЕВА, Д. Петлешкова П. Диагностична стойност на акустичната ринометрия в неонаталния период и ранната кърмаческа възраст. Оториноларингология, ISSN 0473-5609; 2001; 1 : 14-18.

29. Вичева Д. Приложение на акустичната ринометрия в детската възраст. Педиатрия ISSN 0479-7876; 2001; 2: 34-38.

30. Вичева, Д., И. Иовчев, Клинично проучване на ефективността на Azelastine nasal spray при пациенти с целогодишен алергичен ринит посредством акустична ринометрия. Алергия и астма 2001, 2: 50-53.

31. Вичева, Д., Я. Ковачев. Диагностика на алергичния ринит посредством акустична ринометрия. Алергия и астма 2001, 2: 46-49.

32. ВИЧЕВА, Д. Изследване на носните пътища чрез акустична ринометрия. Пьрва национална дискусионна седмица по проблеми на здравеопазването „Тримед“, Пловдив, 15-20.03.2001. CD-ROM

33. ВИЧЕВА, Д. Функционално носно дишане. Международен Бюлетин по оториноларингология, 2005, 2: 43-47.

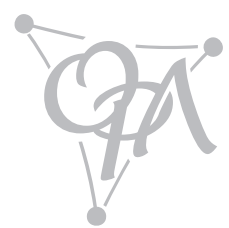

